\title{
The tobacco industry's accounts of refining indirect tobacco advertising in Malaysia
}

\author{
M Assunta, S Chapman
}

Tobacco Control 2004;13(Suppl II):ii63-ii70. doi: 10.1136/tc.2004.008987

See end of article for authors' affiliations

.....................

Correspondence to: Mary Assunta, School of Public Health, Room 129A Edward Ford Building, University of Sydney, Sydney, NSW 2006 Australia; marya@health. usyd.edu.au

\begin{abstract}
Objective: To explore tobacco industry accounts of its use of indirect tobacco advertising and trademark diversification (TMD) in Malaysia, a nation with a reputation for having an abundance of such advertising. Methods: Systematic keyword and opportunistic website searches of formerly private tobacco industry internal documents made available through the Master Settlement Agreement.

Results: 132 documents relevant to the topic were reviewed. TMD efforts were created to advertise cigarettes after advertising restrictions on direct advertising were imposed in 1982. To build public credibility the tobacco companies set up small companies and projected them as entities independent of tobacco. Each brand selected an activity or event such as music, travel, fashion, and sports that best suited its image. RJ Reynolds sponsored music events to advertise its Salem brand while Philip Morris used Marlboro World of Sports since advertising restrictions prevented the use of the Marlboro man in broadcast media. Despite a ban on tobacco advertisements in the mass media, tobacco companies were the top advertisers in the country throughout the 1980s and 1990s. The media's dependence on advertising revenue and support from the ruling elite played a part in delaying efforts to ban indirect advertising. Conclusion: Advertising is crucial for the tobacco industry. When faced with an advertising ban they created ways to circumvent it, such as TMDs.
\end{abstract}

$T$ hough Malaysia is not the birthplace of indirect tobacco advertising, it has had a reputation for having the most widespread forms of this advertising strategy. ${ }^{1}$ The earliest examples of indirect advertising worldwide date back to 1975 with the parallel promotion of Camel boots and cigarettes in Norway. ${ }^{2}$ From 1982 through to the 1990s, Malaysia experienced levels of indirect tobacco advertising unprecedented in any other nation. Despite cynicism from critics, the tobacco transnationals have maintained that these campaigns were not intended to market cigarettes or to circumvent a ban on direct cigarette advertising. The industry refers to the practice as trademark diversification (TMD) initiatives. They involve the establishment of companies for non-tobacco products and naming each after a cigarette brand name. Malaysia offered a fertile political environment for the companies to test new marketing strategies. The Malaysian government was seen as having a "very open and friendly attitude towards business" ${ }^{3}$ and its policy of encouraging foreign investment created an environment conducive to the industry to refine and develop the art of brand stretching in Malaysia. The local tobacco market is dominated by British American Tobacco (BAT) Malaysia, market share 68\%, Japan Tobacco International 17.7\%, and Philip Morris $15.3 \%{ }^{4}$ The companies were able to exert influence as a unified front through the Confederation of Malaysian Tobacco Manufacturers (CMTM) to the government. A history of indirect advertising in Malaysia can now be told in the tobacco companies' own words.

\section{METHODS}

The main data for this paper are based on tobacco industry document searches conducted on the Master Settlement Agreement websites between November 2001 and September 2002: http://www.tobaccoarchives.com/ Additional searches were conducted on secondary document collection websites including Tobacco Documents Online, ${ }^{5}$ Legacy Tobacco Documents Library, ${ }^{6}$ National Clearing House on Tobacco, ${ }^{7}$ and British Columbia's Tobacco Industry Documents site. ${ }^{8}$ To facilitate systematic document analysis initial searches focused on key geographic and company terms representative of Malaysia. The results of these searches were then sorted by date and evaluated according to their degree of importance. During this process, the metadata for documents considered to be of high value were screened for further clues to conduct subsequent searches. A snowballing search strategy was then used where terms from the metadata were formulated into new searches to run on the industry and secondary websites between August and September 2002. For details refer to: http://tobacco.health.usyd.edu.au/site/gateway/docs/ pdf/Malay_Search_Strategy.pdf

The final analysis is based on 132 documents identified to be relevant to this topic. Although BAT has had the longest presence and current market dominance in Malaysia, lack of accessibility to its internal documents from the Guildford depository is a limitation. ${ }^{\circ}$ Additional information was obtained from newspaper articles.

\section{RESULTS}

\section{Using indirect advertising to circumvent the ban}

The tobacco industry in Malaysia has maintained it did not engage in indirect advertising as a way to circumvent the ban on cigarette advertisements, even scorning the suggestion, with the CMTM stating: "There is no such thing as indirect advertising. The products and services advertised are only using the brand names or trademarks of the tobacco companies. They are not related to the root product (cigarettes) at all."10

In most cases TMD had nothing to do with genuine industry efforts to diversify their brand names into

Abbreviations: BAT, British American Tobacco; BWIT, Brown \& Williamson International Tobacco; CMTM, Confederation of Malaysian Tobacco Manufacturers; ITPMS, International Tobacco Products Marketing Standards; MTC, Malaysian Tobacco Company (BAT's local subsidiary); MWOS, Marlboro World Of Sports; NSC, National Sports Council; RJR, RJ Reynolds; RTM, Radio Television Malaysia; TMD, trademark diversifications 
non-tobacco enterprises. ${ }^{11}$ Rather, TMD enabled the tobacco industry worldwide to continue advertising tobacco brand names despite bans on direct cigarette advertisements. BAT's subsidiary Brown \& Williamson International Tobacco (BWIT) in their strategic five year plan for the period 19851989 planned to "Coordinate and fund regional and Operating Company efforts to use alternate communication means where traditional forms are not permitted". ${ }^{12}$

The advent of TMD in Malaysia began when the government banned direct cigarette advertisements from television and radio in March 1982. BAT prepared for this eventuality at its global meeting on the subject ${ }^{13}$ and started "looking into the area of parallel communications via non-tobacco products as a means to safe-guard the names of our current brands..." 14

Advertising is cardinal to the tobacco industry. A 1987 BAT document stated that "advertising is the lifeblood of successful cigarette marketing"15 and that merchandising and promotions, sponsorship and trademark diversification "all contribute to brand image and therefore should consistently project the same image. ...the role and importance of these 'other' media is growing as advertising restrictions increase $\mathrm{e}^{\prime \prime} .^{15}$ In fact BAT reveals the basis of brand choice: "Cigarettes have never been a logical product and brand choice has always been determined by images formed by countless variations of history, tradition, names, slogans and advertising - appealing on an emotional level rather than for rational choice $\overline{\text { "16 }}$ (emphasis in original).

BAT deemed TMD effective if consumers saw the advertisements as promoting cigarettes rather than the product they were ostensibly advertising: “...respondents may take the view that the TMD activity/advertising is designed to promote the cigarette rather than, or in addition to the TMD product itself. Although less positive this would still represent an achievement of the objectives." ${ }^{\prime 17}$

The companies and their advertising agencies used an array of terms to refer to indirect advertising such as "parallel communication", "alibi advertising", "logo licensing", "image transfer advertising", and "below the line advertising". A Hong Kong advertising executive described the difference: "Advertisements (above the line) give the image. Below [the] line activities such as sponsorship of athletics or concerts, sell the product." ${ }^{\prime 18}$

\section{Stretching each brand}

Separate international operating businesses were set up by each tobacco company to develop and run parallel communications to give them independent identities (table 1). These companies set up small businesses such as travel agencies, record shops or clothing stores as front companies and collectively spent millions of dollars advertising tobacco brand names on television, newspapers and billboards (table 2).

Table 1 International companies running the trademark diversification (TMD) business

\begin{tabular}{lll}
\hline Transnational & TMD company & TMD activity \\
\hline British American & World Investment & $\begin{array}{l}\text { Benson \& Hedges Bistro, } \\
\text { Kent Travel }\end{array}$ \\
$\begin{array}{l}\text { Brown \& } \\
\text { Williamson }\end{array}$ & $\begin{array}{l}\text { Diversification } \\
\text { International }\end{array}$ & $\begin{array}{l}\text { Kent Leisure Holidays, Kent } \\
\text { Championship Classics }\end{array}$ \\
Philip Morris & $\begin{array}{l}\text { Products, Inc } \\
\text { International }\end{array}$ & Marlboro Classics \\
RJ Reynolds & $\begin{array}{l}\text { Trademark Inc } \\
\text { Worldwide }\end{array}$ & $\begin{array}{l}\text { Camel Trophy, Camel } \\
\text { Brands, Inc }\end{array}$ \\
& & Stores \\
\hline
\end{tabular}

To build public credibility the tobacco companies projected the TMD companies as being independent entities with BAT, noting that "Fund flows must be confidential". ${ }^{17}$ A BAT document points out the TMD activity should meet several criteria including "Legal feasibility to be defensible; able to survive outside scrutiny and challenge. TMD products/ services should be in Fragmented Markets with no dominant operator." ${ }^{19}$ TMD activities in Malaysia fulfilled these criteria, thereby ensuring the ads' continuation.

All TMD activities were controlled completely by the tobacco companies. In 1979, when BAT internationally outlined the need to research and develop TMD, its guidelines indicated: "The formulation of the concepts and the checking and vetting of the operation must be in the hands of the Company, and not left to outside agencies who seldom appreciate the finer aspects of the cigarette business. Management of the operation should be integrated into the cigarette brand management, both to ensure correct images and to provide increased job motivation and enrichment for cigarette people." 20

\section{Vacation, travel and all that jazz}

BWIT's International Brand Management assisted Malaysian Tobacco Company (MTC) to develop its TMD Kent ads tied in with Club Mediterranea which featured Kent props. MTC planned to extend this parallel activity into "Exotic Haven" Books and an eventual regional tie-in between Kent and vacation advertising: "We agreed that this was a good avenue for advertising Kent, given the current restrictions in Malaysia. ...The [advertising] agency presented their Lucky Strike Filter campaign featuring a very fast pace use of the bull's eye-mnemonic which we felt was to be very impactful [sic] in view of the current restrictions." ${ }^{22}$ In 1988, BWIT advised that a price reduction of Lucky Strike should be undertaken together with a full relaunch with heavy sampling and TMD support: "We fully agree that a TV/TMD campaign is necessary. As you say this is the core to communicating the brand ...Without brand image footage, we believe a relaunch will be severely hampered." ${ }^{23}$

With substantial budgets allocated to marketing, advertising agencies stood to benefit handsomely in securing accounts from tobacco companies and worked closely with them. MTC reported: “...MTC's advertising agency-KHK Needham-acts in practice very much as an extension of MTC's own marketing department. Their key executives are as much aware of market information, trends, brands, developments and research, as are some of MTC's key Marketing people." 24

Indirect cigarette advertisements closely resembled direct advertisements. MTC illustrated this in their Kent "Beach House" and "Sail-Boat" indirect advertisements: "Bear in mind that our commercials are for diversification, if there are potential flaws in the original cigarette commercials, then these are always exacerbated in the non-cigarette adaptations." 25

B\&W chose music as its principal means to diversify advertising for its Kool brand, arguing "KOOL must be positioned primarily in image, not product, terms. The brand's international development depends on association of KOOL with the leading edge of trends among hedonistic young (21-30), urban adult male (not excluding female) smokers." ${ }^{26}$ Advertising firm KHK Needham Standard developed a brief for a parallel communication advertising campaign associating Kool with music for launch in Malaysia. Its indirect objective: "To achieve an association of 'Kool is Jazz. And Jazz is Kool'... To ensure that the opportunities provide effective means of advertising in media otherwise unavailable." ${ }^{\prime 27}$ To legitimise this parallel communication, a local company Kool Jazz Promotions Sdn [Pte] 
Table 2 Trademark diversification activities of cigarette brands in Malaysia in 1989.21

\begin{tabular}{|c|c|c|c|c|}
\hline Company & Premium brands & Logo licence & $\begin{array}{l}\text { Sponsorship } \\
\text { special event }\end{array}$ & $\begin{array}{l}\text { Sponsorship TV } \\
\text { programme }\end{array}$ \\
\hline MTC & Benson \& Hedges & Gold Centre & Golf & Mini series \\
\hline MTC & Gold Flake & - & - & Drama series \\
\hline MTC & John Player Special & JPS Cologne & Polo & Mini series \\
\hline MTC & Kent & Kent Holidays & Bowling, regatta & Musical serials \\
\hline MTC & Kingsway & Kingsway Sensation & Concerts & Musical \\
\hline MTC & Lucky Strike & L.S. Rally Shop & Motor racing & Movies \\
\hline MTC & Players Gold Leaf & - & - & Movies \\
\hline Philip Morris & Marlboro & Marlboro Country (Travel) & Badminton & Movies \\
\hline RJ Reynolds & Camel & Camel Adventure Gear & - & Formula 1 racing \\
\hline RJ Reynolds & More & More Style & James Bond & TV serials \\
\hline RJ Reynolds & Salem & Salem High Country & Concerts, disco & $\begin{array}{l}\text { Musicals, sports, } \\
\text { Formula } 1 \text { racing }\end{array}$ \\
\hline Rothmans & Dunhill & Dunhill Shop & Soccer & $\begin{array}{l}\text { Mini series, movies, } \\
\text { sports }\end{array}$ \\
\hline Rothmans & Perilly's & $\begin{array}{l}\text { Black \& Gold Collection } \\
\text { from Porsche Design }\end{array}$ & - & - \\
\hline Rothmans & Peter Stuyvesant & P.S. Travel & Bowling, concert & Documentaries \\
\hline Rothmans & Rothmans & Rothmans Executive Travel & $\begin{array}{l}\text { Soccer, boxing, } \\
\text { snooker }\end{array}$ & Sports \\
\hline Rothmans & Virginia Gold & - & - & Movies, musical \\
\hline Rothmans & White Horse & - & - & Sports \\
\hline
\end{tabular}

Bhd [Ltd] was set up. The advertising brief points out the suitability of associating Kool with jazz because the Malaysian government guidelines for television discouraged the promotion of foreign hip culture and jazz was seen as being "wholesome, positive and exclusive" in contrast to rock concerts which were associated with "Woodstock, 'hippies', dope, etc. ${ }^{27}$

\section{Keeping a young image through pop concerts and movies}

Through the 1980s and 1990s Malaysians were exposed to numerous prime time and all media advertisements for Salem High Country Holidays and Salem Cool Planet. In 1989, RJR Malaysia outlined its marketing plan for Salem "logo license" and "thematic advertising". Top priority was to communicate the product as the "ultimate in refreshment" where the user is "young, contemporary, stylish, [with a] pleasure seeking lifestyle" ${ }^{\prime 21}$ It would use music to reinforce Salem's image through TV programmes sponsorship and concerts featuring international and local performing artists. Marketing activities were to be carried out in discos and music shops. ${ }^{21}$

RJR continued to use music in Malaysia through the 1990s (fig 1). RJR saw the fruits of years of tactical advertising when Salem become the second largest selling brand in Malaysia in $1995 .^{28}$ The programmes ranged from "action packed movies and tennis to contemporary music and dance" ${ }^{\prime 29} 30$

\section{Sports sponsorship advertises cigarettes}

In 1979, BAT outlined the advantages of sponsored activities, which included the sale of items associated with the sponsorship carrying the brand name and using pack faces or inserts to publicise the sponsorship activity. ${ }^{20}$ By 1992, sponsorship took on a more prominent role because it was the last domain to be unregulated. BAT stated sponsorship provides "...publicity to the target market-not just in volume but in quality as well...Thus sponsorship is proportionately more important to a tobacco company as it is still widely available." ${ }^{\prime 31}$

In Malaysia restrictions presented "no problems, only opportunities" to MTC. ${ }^{24}$ When advertising restrictions increased, anticipatory use of brand name advertising had already solved the problem. As pointed out by B\&W: “...the tightening communications situation has created a position in which sponsorship advertising is one of the few ways left through which cigarette names can be publicised in an interesting way." ${ }^{24}$ Learning from the success of Philip Morris, BAT noted all sponsored events must carry the brand name in the title since "symbol exploitation now establishes another shorthand way of saying Marlboro". ${ }^{32}$

Tobacco company research helped point to sports that were liked by smokers. In 1987, Philip Morris' General Consumer Survey revealed football, badminton, sepak takraw (local ball game) and snooker were the top four sports most often watched and played by Malaysian smokers. ${ }^{33}$ These sports were all selected for sponsorship (fig 2). Philip Morris also sponsored motor racing because it best suited the tough Marlboro image: "The extension of the tough, outdoor, 'cowboy' hero-now on wheels instead of a horse-is credible and authentic."16 It established the Marlboro World Of Sports (MWOS), a television series to "capture the spirit of Marlboro within a high action, high tech ambience. The cornerstone of our [M]WOS program is $\mathrm{F}-1$, which is highly targeted, heroic and international." ${ }^{34}$ Through this sponsorship it secured continued visibility for Marlboro on television: "In the coming years, we continue to foresee supporting MWOS with the emphasis on bikes - playing a major role in our communications and local promotions strategies, and providing us programming leverage with the TV stations to maintain Marlboro visibility during the racing season." ${ }^{35}$

An MTC marketing report documents how indirect advertising and sponsorship activities were carried out to support the launch of a new brand: "The brand was given very heavy support in all the media. The sponsorship of the Pre-World Cup telecast and the World Cup [1986] live telecast was supported extensively by press ads in all major newspapers. In conjunction with the World Cup, various competitions were organised in the leading newspapers... Additionally, the new B\&H Special Filter product ad. with the headline World's No. I Virginia was also launched." ${ }^{36}$ MTC forecast that the sports sponsorship and advertising activities by MTC will increase cigarette sales. ${ }^{36}$

Philip Morris' business expansion plan for Malaysia in 1994 identified restrictions on advertising as a "threat" and proposed to "...increase the value of the Marlboro trademark in Malaysia through active trademark diversification [advertising] programs" in all media. ${ }^{37}$ Its three year plan 

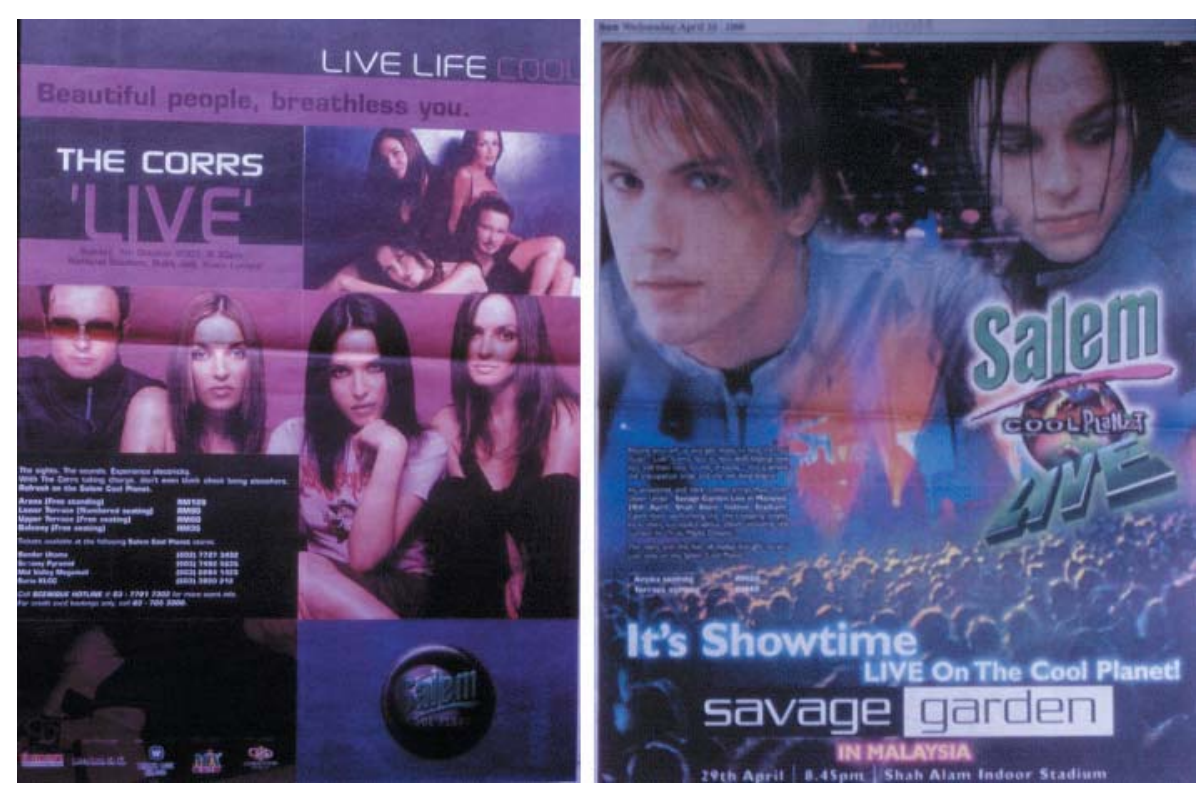

Figure 1 Examples of newspaper advertisements for Salem sponsorship of pop concerts in Kuala Lumpur.

1994-1996 outlined how to maintain Marlboro's presence in the regular media and communication strategies included: "The Rev-It-Up Events and TGMP [targeted group meeting point] sampling programs are designed to create impact excitement in major markets with a live concerts [sic], mechanical bull riding, bar fly jumping, along with product sales and country premiums." ${ }^{138}$ In 1994, Watson Creative in developing the blueprint for the marketing and advertising of Philip Morris' Chesterfield, proposed the establishment of Chesterfield Legend Stores in Kuala Lumpur that would "develop a strong gravitational pull upon the YAMS [young adult male smokers]... Only TMD remains a viable long term resource that can sustain visibility and translate into income." ${ }^{\prime 39}$

Sponsorship of the 1998 Commonwealth Games in Malaysia

The Commonwealth Games has a smoke-free policy. Its constitution states: "No advertisements of any kind to promote Tobacco or by companies who are principally engaged in the sale of tobacco or tobacco products will be permitted." 4041 Malaysia hosted the 16th Commonwealth
Games in Kuala Lumpur in 1998. Contrary to the Games' constitution, tobacco companies sponsored the Games through the National Sports Council (NSC). The fact of tobacco sponsorship of the Games being against the Games constitution was never made public.

In 1993, the Malaysian Sports Minister announced that cigarette companies could continue to be active in sports and welcomed them to sponsor and contribute to the 1998 Commonwealth Games Fund.$^{42}$ BAT informed MTC it would sponsor the 1998 Commonwealth Games in Malaysia: "The industry will channel funds through the National Sports Council (an existing organization) and not directly to the Commonwealth Games Foundation. NSC will write to the tobacco companies inviting financial contributions. Effectively the Industry will be allowed to 'sponsor' the aims and work of the NSC and the Industry will seek limited publicity so that contributions can be managed as a brand operating expense, thus avoiding the need for specific disclosure in annual reports... The Industry is proposing to contribute RM250 mns. [approximately £66 million at current exchange rates] over five year period, beginning January $1994 \ldots{ }^{\prime 43}$
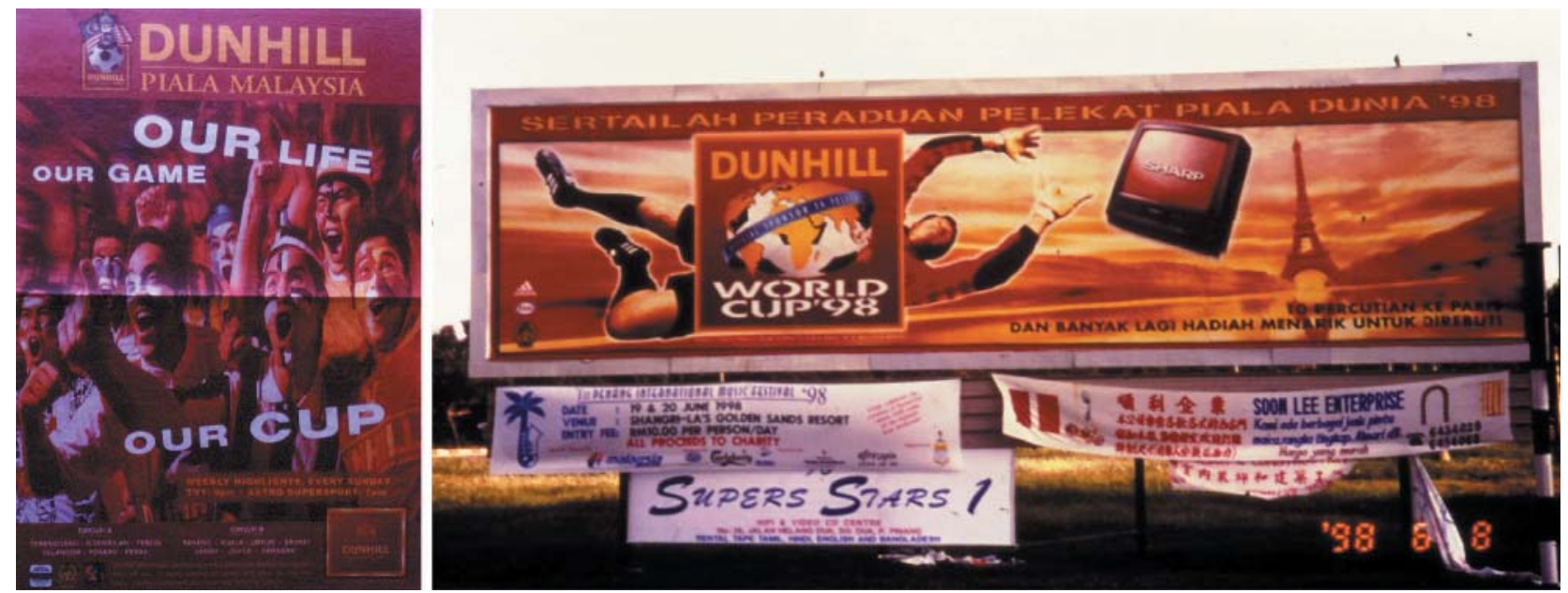

Figure 2 Advertisements of Dunhill sponsorship of national and world football events. 
BAT provided advice on handling the public when it became widely known about MTC's sponsorship of the Commonwealth Games: “...the industry in Malaysia assumes that the above sponsorship becomes public knowledge and open to enquiry. As such, it would probably be a good idea to develop common, agreed-by-the-industry Questions and Answers on the assumption of probing." ${ }^{44}$ The tobacco companies' pledge in sponsorship for the Games well exceeded the projected total cost of the Games, which in 1994 was estimated to be up to US\$52.6 million (RM200 million). ${ }^{45}$ However the Commonwealth Games Foundation itself was unaware of the sponsorship. An official from the Games Foundation confirmed "...if there was any hint of a deal between 'the 1998 Commonwealth Games' and tobacco associated companies, it would have been squashed hard early on". ${ }^{41}$

\section{Malaysia used as testing ground}

In 1994, BAT developed a new Benson \& Hedges television commercial with a "golden" theme, intended as a global advertising strategy for its TMD, and was first screen tested in Malaysia: "This [commercial] will be used firstly in Malaysia and thereafter (1995) made available for international use...Malaysia has successfully implemented a consumer DM [direct marketing] programme. The IBG, [International Brand Group] together with Malaysia, will provide a case history for review by other markets in Q2 [second quarter] 1994." ${ }^{\prime 46}$

In 1998, with the tightening up of advertising restrictions in the European Union, the importance of expanding TMD became even more apparent. A Benson \& Hedges branded coffee campaign was developed by a London based agency in an effort to circumvent the pending European ban. The rationale was, if advertising cigarettes was not allowed, then
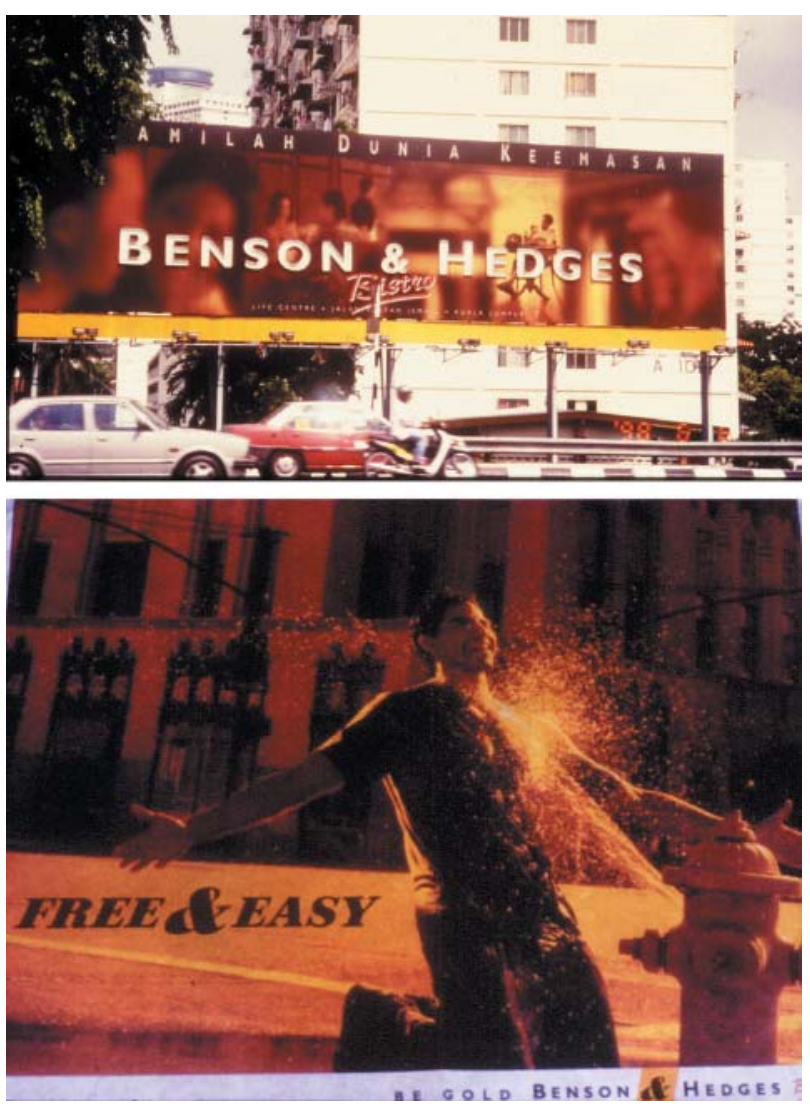

Figure 3 Examples of Benson \& Hedges Bistro advertisements. advertising coffee would have a halo effect on the cigarette brand. Mass media advertisements featuring Benson \& Hedges and a coffee bistro were screen tested in Malaysia ${ }^{47}$ (fig 3). The Bistro's manager described the purpose of the Bistro: "Of course this is all about keeping the Benson \& Hedges brand name to the front. We advertise the Benson \& Hedges Bistro on television and in the newspapers. The idea is to be smoker friendly. Smokers associate a coffee with a cigarette. They are both drugs of a type."47

\section{Indirect advertising's proportion of the advertising dollar}

When the industry's voluntary International Tobacco Products Marketing Standards was implemented in 2002, the transnationals agreed to stop advertising in the mass media and sponsoring activities. ${ }^{48}$ The same year BAT disposed of its Alfred Dunhill of London business confirming the business legitimised its indirect advertising activities. That small non-tobacco business venture did not justify the vast sums spent advertising the brand: "Dunhill spent $\$ 2.8$ million on advertising the shop and associated items in 1983; a sum that certainly cannot be supported by the size of the small and loss making non-tobacco business." ${ }^{49}$

Despite the ban on cigarette advertisements over television and radio since 1982, extended to all mass media in 1994, tobacco companies were among the top advertisers in the country through the 1980s and 1990s. In 1986, MTC reported it had $75 \%$ of the volume of television advertising on Radio Television Malaysia, the government television station, compared to Rothmans and RJR (fig 4). On the private station TV3, Rothmans dominated the volume with $64 \%$ compared to MTC and RJR. ${ }^{36}$ In 1987, US\$25 million was spent on tobacco advertising, which increased to US\$32 million the following year. ${ }^{50}$ In 1991 RJR's Salem was the "most strongly advertised" brand of any product in Malaysia with a budget of US\$3.5 million (M\$13.59 million $)^{51}$ spent mostly on television. In the mid 1990s, tobacco companies became the number one advertisers in the country occupying $25 \%$ of total national advertising expenditure. ${ }^{52}$

Advertising remained a large part of the tobacco companies' operating costs into 2000, spending about US\$40million a year advertising their brands. ${ }^{53}$ BAT Malaysia's advertising constituted about 26-28\% of its total operating cost. However, this expenditure does not reflect the insignificant revenue derived from its trademark business. Its TDM

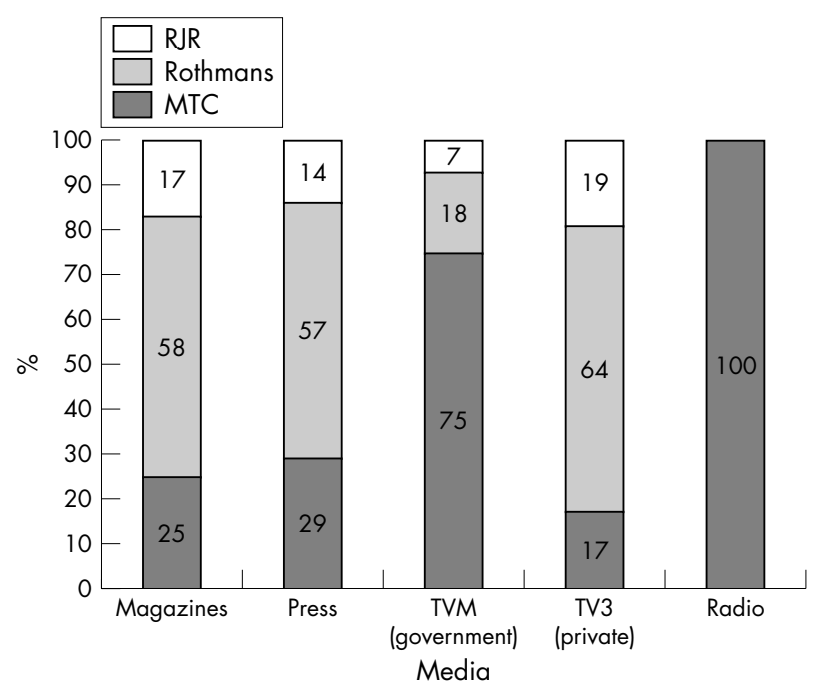

Figure 4 Share of voice: tobacco advertising in Malaysia, April-June $1986 .{ }^{36}$ 
business, for example, contributed less than $0.1 \%$ of the company's total revenue. ${ }^{53}$

\section{VIP support for indirect advertising and tobacco sponsorship}

The tobacco industry in Malaysia ensured it enlisted endorsement for its indirect advertising and sponsorship activities from the very top leadership in Malaysia including the King, the Prime Minister, and cabinet ministers. These endorsements (below) received good media coverage and may well have served to subtly discourage efforts to ban indirect advertising in Malaysia.

In July 1992, the Malaysian Ministry of Health announced it was drawing up tobacco control legislation that would prohibit all direct and indirect advertisements. The Ministry also indicated that despite facing much opposition, it was determined to enforce the regulations by the end of $1992 .^{54}$ However over the next 10 years the debate went back and forth and finally the government relented on its initial decision to ban indirect advertising. The see-sawing between the decision to prohibit or not to prohibit these advertisements was most likely influenced by the tobacco industry having support from among top political leadership within the government. Marlboro's sponsorship of motor racing events, for example, assisted the then Prime Minister in his quest to bring Formula $\mathrm{l}$ to Malaysia. The Marlboro Malaysian Grand Prix in April 1997 was flagged off by the Prime Minister. ${ }^{55-57}$ In 2001, Formula 1 racing was held in Malaysia for the first time.

The tobacco industry in Malaysia had a supporter in the Minister of Information who was in charge of the government run radio and television station, RTM. In the mid 1990s RTM was earning about $40 \%$ of its advertising revenue from tobacco companies and the Minister indicated the station could not do without tobacco money. ${ }^{58}$ Although the Malaysian Health Ministry, consumer groups, and the public health community called for the total ban on all forms of tobacco advertising, the Information Minister actively defended the tobacco industry and officiated at its functions. In 1996, he announced the existing government policy on indirect advertising by cigarette companies to advertise products and services using their trademark will remain because it was legitimate..$^{59}$ In 1997, he announced that the regulations to halt indirect cigarette advertisements in the electronic and print media were difficult to implement. ${ }^{60}$ Philip Morris attributed indirect advertising to the Malaysian government's need for revenue: “...the government wants and needs revenue, and various ministries and departments continuously ask manufacturers for more TV, more sponsorships and more contributions; and, finally, because all of our competitors are local companies, with local shareholders, who accept and support Malaysian practices and frequently provide cover and support with Malaysian officials." ${ }^{\prime 1}$

\section{DISCUSSION}

The examples of indirect advertising cited above are by no means an exhaustive list of the promotional activities carried out by the tobacco companies in Malaysia. ${ }^{32}$ It is clear that despite a ban on direct cigarette advertising, the industry successfully engaged in indirect advertising for two decades because of support and approval from the country's top leadership. Criticism against the ruling elite is not encouraged and dissenting views critical of politicians from the ruling coalition are seen as anti-government. The ruling elite's leadership of sports bodies helped to facilitate the continuance of tobacco sponsorship. The media's dependence on advertising revenue from tobacco companies severely limited its coverage of criticisms against indirect advertising. Combined, these factors curbed almost all public protest
What this paper adds

This paper is the first to examine tobacco companies' brand stretching in a developing nation. It illustrates how, despite tobacco advertising ban, tobacco companies were top advertisers in a developing country.

against such promotions and hampered support for a legislative ban.

In September 2001, Philip Morris, BAT, and Japan Tobacco International announced their new self regulation effort through the International Tobacco Products Marketing Standards (ITPMS) which came into force in December 2002. These guidelines claim to stop the kind of indirect advertising and sponsorship activities described above. Soon after the announcement of the global standards, BAT Malaysia announced its disposal of the Dunhill merchandising business. This illustrates that this business had existed to facilitate indirect advertising and could now be dispensed with since BAT had decided to cease such promotions. However, BAT indicated it will not reduce its advertising budget in Malaysia, instead it will increase it $^{62}$ and step up promotions and other forms of direct advertisements at point-of-sale. ${ }^{63}$ This confirms advertising is the lifeblood of cigarette marketing and crucial for the survival of the industry as illustrated in the documents. The small number of BAT documents reviewed is a limitation considering BAT's long presence in Malaysia and its market dominance since November 1999. These documents could have provided further insight into their indirect advertising strategies.

The industry's ITPMS is subject to national contracts, which rendered the December 2002 deadline flexible. In Malaysia, despite the industry's announcement to cease indirect advertising and sponsorships, Dunhill's sponsorship of soccer will continue until the contract expires in 2004. In May 2002, Malaysia was the focus of international attention when BAT's Dunhill sponsored the telecasts of a tobacco-free World Cup, ${ }^{64}$ although FIFA in 2000 officially announced an agreement that the 2002 and 2006 World Cup finals will “...explicitly exclude the right to appoint sponsors from any tobacco-related category" ${ }^{\prime 65}$ The value of sports sponsorship translating into cigarette advertising and better sales still hold true for the tobacco companies, more so for Dunhill that has been the number one cigarette brand in the country and the top consumer brand in 2002. ${ }^{66}$

In August 2002, the Minister of Health announced a ban on all forms of promotions of cigarette brand names in Malaysia effective 1 January 2003 with exemptions for soccer, motor racing, ${ }^{67}$ and sepak takraw. ${ }^{68}$ As of mid 2004, this announcement had not translated into law. In the absence of the law, the companies have continued with sponsorship activities such as Salem Craig David concert ${ }^{69}$ and Mild Seven Outdoor Quest ${ }^{70}$ in 2003. Industry self regulation has failed again as it has for the past two decades.

In conclusion, the documents provide evidence that even when there was a ban on cigarette advertising, the industry circumvented it. Malaysia's experience in indirect advertising clearly illustrates that a partial ban on advertising in select media is ineffective and exemplifies the need for comprehensive legislation banning all forms of tobacco advertising, sponsorship, and promotional activities. The Framework Convention on Tobacco Control, which provides the legal framework for such legislation, gives Malaysia an excellent opportunity to move forward on this issue. 


\section{ACKNOWLEDGEMENTS}

Thanks are due to Fiona Byrne for her invaluable input and information management, and reviewers for comments. The research reported in this paper was supported by grants from the National Health and Medical Research Council (2001-2003\#153857) and the US National Institutes of Health (2001-2005\#R01CA87110-01A1).

\section{Authors' affiliations}

M Assunta, S Chapman, School of Public Health, University of Sydney, Sydney, NSW, Australia

\section{REFERENCES}

1 World Health Organization. Factsheet: smoking statistics. World Health Organization, Regional Office for the Western Pacific, 2002. http:// www.wpro.who.int [Accessed 20 Aug 2003].

2 Action on Smoking \& Health. ASH briefing on "brand-stretching". London: ASH UK, 1998.

3 Phang S. Contraband cigarettes a threat. The Edge (Kuala Lumpur, Malaysia) Oct 16 2000:73.

4 Kuan M. BAT, JTI still favourites for defensive quality. The Edge Daily (Kuala Lumpur, Malaysia) 20 Mar 2003. http://www.theedgedaily.com/cms/ index.jsp [Accessed 24 Mar 2003].

5 Tobacco Documents Online. http://tobaccodocuments.org.

6 Legacy Tobacco Documents Library. University of California, San Francisco. http://legacy.library.ucsf.edu.

7 National Clearinghouse on Tobacco and Health Program Guildford documents collection. Canadian Council for Tobacco Control. http:// www.ncth.ca/Guildford.nsf.

8 British Columbia's Tobacco Industry Documents. Government of British Columbia, Ministry of Health Services. http://www.moh.hnet.bc.ca/cgi-bin/ guildford_search.cgi.

9 Lee K, Gilmore $A B$, Collin J. Looking inside the tobacco industry: revealing insights from the Guildford Depository. Addiction 2004;99:394-7.

10 Kang SL. No immediate plans for tobacco ad clampdown. Business Times (Kuala Lumpur, Malaysia) 14 Aug 1996:17.

11 Joossens L. How to circumvent tobacco advertising restrictions: the irrelevance of the distinction between direct and indirect advertising. UICC GLOBALink, 2001. http://www.globalink.org/tobacco/docs/eu-docs/ 0102joossens.shtml [Accessed 23 Dec 2002].

12 Brown \& Williamson International Tobacco. Brown \& Williamson international strategic marketing plan, 1985-1989. Jul 1984. Brown \& Williamson. Bates No. 690114245/4258. http://legacy.library.ucsf.edu/ $\mathrm{tid} / \mathrm{wmr} 13 \mathrm{fOO}$.

13 British American Tobacco. Marketing Low Delivery Products Conference, January 17th-22nd, 1982, Royal Garden Hotel, Kensington: provisional programme. 13 Oct 1981. Brown \& Williamson. Bates No.670126726/ 6732. http://legacy.library.ucsf.edu/tid/trf14f00.

14 Hong O. Malaysian Tobacco Company. Registration of Kent trade mark in classes other than class 34 in Malaya, Sabah \& Sarawak. 15 Dec 1982. Brown \& Williamson. Bates No. 682141504/1505. http:// legacy.library.ucsf.edu/tid/isp01f00.

15 Speakman J. Cigarette advertising: "Getting the message across". 25 Sep 1987. British American Tobacco. Bates No. $301621741 / 1754$. http:// tobaccodocuments.org/health_canada/R2458_0.pdf [Accessed 30 May 2002].

16 The vanishing media. undated. British American Tobacco. Bates No. 500062147/2159. http://www. library.ucsf.edu/tobacco/batco/html/300/ 367 [Accessed 1 Aug 2002]

17 British American Tobacco. [Background to trademark diversification]. undated. British American Tobacco. Bates No. 502594957/4964. http:// www.moh.hnet.bc.ca/guildford/html/067/00006807.html [Accessed 1 Aug 2002].

18 United Press International. Hong Kong bans cigarette advertising on TV. 30 Nov 1990. Philip Morris. Bates No. 2021589649. http:// legacy.library.ucsf.edu/tid/Iwb68e00.

19 British American Tobacco. Trademark diversification. 14 May 1991. British American Tobacco. Bates No. 502594945/4952. http:// tobacco.health.usyd.edu.au/tds/BAT502594945_4952 [Accessed 25 Nov 2002].

20 British American Tobacco. Guidelines on communication restrictions and new opportunities in marketing, Jesteburg, 13th-17th May, 1979. May 1979 Brown \& Williamson. Bates No. 621054741/4756. http:// legacy.library.ucsf.edu/tid/Itp21 foo.

21 Blackburn D. Malaysia: market analysis. 29 Jun 1989. R.J. Reynolds. Bates No. 516414191/4210. http://legacy.library.ucsf.edu/tid/cpy82d00.

22 Whitehair TE. Visit report - Malaysia, 7-10 October 1981. 26 Oct 1981 Brown \& Williamson. Bates No. 660060309/0314. http:// legacy.library.ucsf.edu/tid/fwo $89 \mathrm{e} 00$.

23 Birch P. Lucky Strike filters. 14 Oct 1988. Brown \& Williamson. Bates No. 621617609/7610. http://legacy.library.ucsf.edu/tid/ooo70foo.

24 British American Tobacco. BAT marketing news: special Malaysia issue. Jun 1983. Brown \& Williamson. Bates No. 670229117/9152. http:// legacy.library.ucsf.edu/tid/bqx13f00.

25 Jones RW. Malaysian Tobacco Company Bhd. Kent "beach house" and "sailboat". 16 Jun 1989. Brown \& Williamson. Bates No. 464526958. http:// legacy.library.ucsf.edu/tid/zfx43f00.
26 Brown \& Williamson. KOOL: Parallel Communications/Trademark Diversification (PC/TD) strategy. undated. Brown \& Williamson. Bates No. 660908714/8715. http://legacy.library.ucsf.edu/tid/wqg90fo0.

27 KHK Needham Standard Sdn Bhd. Kool and Jazz: a proposal on parallel communications. 15 Jul 1983. Brown \& Williamson. Bates No. 670877137/ 7167. http://legacy.library.ucsf.edu/tid/aof21fo0.

28 RJ Reynolds Berhad. Annual report 1995.

29 Griscom TC. Highlights of August 1997 external relations activities and issues worldwide. 3 Sep 1997. R.J. Reynolds. Bates No. 517115934/5942. http:// legacy.library.ucsf.edu/tid/vnb51d00.

30 Griscom TC. Highlights of July 1997 external relations activities and issues worldwide. 5 Aug 1997. R.J. Reynolds. Bates No. 517115950/5966. http:// legacy.library.ucsf.edu/tid/wnb51d00.

31 Howley J. Map XII Project: effective marketing without media advertising. May 1982. Brown \& Williamson. Bates No. 516009605/9636. http:// legacy.library.ucsf.edu/tid/fyj10f00.

32 Hacking I. Management Action Program 12: effective marketing without media advertising recommendations. 5 Feb 1981. Brown \& Williamson. Bates No. 670132265/2284. http://legacy.library.ucsf.edu/tid/rvw79e00.

33 Lok H. West Malaysia GCS 1987. 30 Dec 1987. Philip Morris. Bates No. 2504047181/7221. http://legacy.library.ucsf.edu/tid/svt19e00.

34 Philip Morris. Marlboro. 1990. Philip Morris. Bates No. 2504004484A 4498. http://legacy.library.ucsf.edu/tid/yuul9e00.

35 Schmidt PN. Godfrey Phillips. F1 and bikes evaluation - Malaysia. 3 Jun 1993. Philip Morris. Bates No. 2504052857/2859. http:// legacy.library.ucsf.edu/tid/byw32e00.

36 Malaysian Tobacco Company Berhad. Quarterly marketing report for quarter 2, 1986 (April-June 1986). Jun 1986. Brown \& Williamson. Bates No. 620418919/8930. http://legacy.library.ucsf.edu/tid/pij61fo0.

37 Philip Morris. Malaysia OB 1994. 1994. Philip Morris. Bates No. 2504032752/2779. http://legacy.library.ucsf.edu/tid/qpq19e00

38 Philip Morris. Malaysia: 3 year plan 1994 to 1996. 1994. Philip Morris. Bates No. 2504033230/3262. http://legacy.library.ucsf.edu/tid/ epq19e00.

39 Watson Creative Marketing. TMD for Marlboro and Chesterfield. Jan 1994 Philip Morris. Bates No. 2504015636/5736. http://legacy.library.ucsf.edu/ $\mathrm{tid} / \mathrm{mka} 42 \mathrm{e} 00$

40 Commonwealth Games Federation. Constitution. Commonwealth Games Federation. 2002. http://www.thecgf.com/about/constitution.pdf [Accessed 13 Jan 2003].

41 Lockhart M. Smoke-free policy. Personal communication, 21 Aug 2002.

42 Singh R. Smoke signals for '89. The New Straits Times (Kuala Lumpur, Malaysia). 13 Apr 1993:1. LexisNexis - All News. [Accessed 7 Jan 2003]

43 Adams P. Malaysian Tobacco Company - Commonwealth Games. 10 Dec 1993. British American Tobacco. Bates No. 500015741. http:// tobaccodocuments.org/guildford_misc/500015741.html [Accessed 1 Aug 2002].

44 Adams P. NSC sponsorship. 17 Nov 1993. British American Tobacco. Bates No.500015801. http://tobaccodocuments.org/guildford_misc/ 500015801.html [Accessed 1 Aug 2002]

45 Anon. Sukom raises RM42m so far. The New Straits Times (Kuala Lumpur Malaysia) 19 Jul 1994. LexisNexis - All News. [Accessed 7 Jan 2003].

46 Fell D. Benson \& Hedges 1994 brand plans. Mar 1994. British American Tobacco. Bates No. 502609298/9320. http://tobaccodocuments.org/ health_canada/R1536_30.html [Accessed 1 Aug 2002].

47 Nuki P. Tobacco firms brew up coffee to beat ad ban. Sunday Times (UK) 18 Jan 1998. LexisNexis - All News. [Accessed 7 Jan 2003].

48 British American Tobacco. International Tobacco Products Marketing Standards. British American Tobacco (Malaysia). 2002. http:// www.batmalaysia.com/subnav/marketingstandard/index.htm [Accessed 4 Sep 2002]

49 Johnson OW. Case study Malaysia: Marketing Managers Course. Jan 1985 British American Tobacco. Bates No. 100574881/5027. http:// www.tobaccodocuments.org/health_canada/10057488.html [Accessed 29 Nov 2002]

50 National Poison Centre. Summary of action and events. http:// www.prn.usm.my [Accessed 29 Nov 2002]

51 Tan CS. Salem 'most strongly advertised brand'. Business Times (Kuala Lumpur, Malaysia). 25 Feb 1991:1. LexisNexis - All News. [Accessed 7 Jan 2003].

52 Warner F. Asian Wall Street Journal. Smoke screen: tobacco companies invent more ways to skirt ad bans. 6 Aug 1996. Philip Morris. Bates No. 2071626482/6485. http://legacy.library.ucsf.edu/tid/pco37d00.

53 Phang S. Hey, big spender. The Edge (Kuala Lumpur, Malaysia) 16 Oct 2000:73.

54 Anon. Tobacco rules to be enforced this year: Farid. Business Times (Kuala Lumpur, Malaysia) 29 Jul 1992. http://www.emedia.com.my/Services/ database.html [Accessed 31 May 2002].

55 Anon. Mahathir boost for MAB. The New Straits Times (Kuala Lumpur, Malaysia). 8 Mar 1997:43. LexisNexis - All News. [Accessed 7 Jan 2003].

56 Ghazali F. Dr M opens the Marlboro Malaysia Grand Prix '97. Business Times (Kuala Lumpur, Malaysia). 14 Apr 1997:20. LexisNexis - All News. [Accessed 7 Jan 2003]

57 Anon. Prime Minister to flag off glamour race. The New Straits Times (Kuala Lumpur, Malaysia). 8 Apr 1997:44. LexisNexis - All News [Accessed 7 Jan 2003].

58 Anon. Government softens stand on smoking ban. Business Times (Kuala Lumpur, Malaysia) 14 Feb 1997.

59 Anon. No plan to scrap indirect advertising by cigarette firms. The New Straits Times (Kuala Lumpur, Malaysia) 15 May 1996:7. 
$60 \mathrm{Ng} \mathrm{V}$. Tobacco companies' ads to remain. New Sunday Times (Kuala Lumpur, Malaysia) 26 Jan 1996:1.

61 Philip Morris. Corporate Affairs. 1990. Philip Morris. Bates No. 2074188556/8612. http://legacy.library.ucsf.edu/tid/sgk45c00

62 Yap. New marketing standards for tobacco companies. The Star (Malaysia) 21 Dec 2002

63 Paul Raj A. Tobacco giants initiate tough marketing rules. Business Times (Kuala Lumpur, Malaysia) 31 Oct 2001:1.

64 Assunta M. BAT flouts tobacco-free World Cup policy. Tobacco Control 2002;11:277-8.

65 Cooper K, Federation Internationale de Football Association. Tobacco sponsorship in football: the position of FIFA: presentation to the public hearings on the WHO Framework Convention for Tobacco Control, 12-13 October 2000. Geneva. World Health Organization, Western Pacific Region,
2000. http://www.wpro.who.int/pdf/tfi/sports_doc/

Federation\%20Internationale\%20de\%20Football\%20Association.doc [Accessed 23 Dec 2002].

66 Mahpar MH. Dunhill claims top brand spot in Malaysia. The Star (Malaysia) 19 July 2002:6.

67 Simpson D. Malaysia: racing round the hurdles. Tobacco Control 2004; 13:106-7.

68 Bernama. Ban on all forms of cigarette promos from Jan 1, 2003. Bernama Daily Malaysian News 20 Aug 2002. LexisNexis - All News [Accessed 7 Jan 2003].

69 AFP. Health group's plea to British pop star. The Star (Malaysia) 5 Oct 2003. http://www.thestar.com.my [Accessed 5 Oct 2003].

70 Promotional Campaigns (Asia) Ltd. Mild Seven Outdoor Quest 2003, http:// wwwl.msoq.com/2003/en/faq.asp\#faq03 [Accessed 18 Feb 2004]. 